\title{
Role of Antioxidant Enzymes in Glucose and Lipid Metabolism in Association with Obesityand Type 2 Diabetes
}

\author{
Kandi Sabitha $^{1, *}$, B. Venugopal ${ }^{1}$, Md Rafi ${ }^{1}$, K V Ramana ${ }^{2}$ \\ ${ }^{1}$ Chalmeda AnandRao Institute of Medical Sciences, Bommakal, Karimnagar, Andhra Pradesh \\ ${ }^{2}$ Prathima institute of Medical Sciences, Nagnur, Karimnagar, Andhra Pradesh \\ *Corresponding author: tejaswani19@gmail.com
}

Received January 26, 2014; Revised February 16, 2014; Accepted February 21, 2014

\begin{abstract}
Introduction: Obesity is a state of excess adipose tissue mass. It can be calculated by BMI or waist circumference. Waist circumference more than $88 \mathrm{~cm}$ in female and $102 \mathrm{~cm}$ in males make them overweight and these overweight increases 2.9 times the risk of metabolic syndrome, type 2 diabetes. The antioxidant enzymes SOD (Superoxide Dismutase), MDA (Malondialdehyde) levels are assayed in these overwight and risk category (gentic risk). Materials \& Methods: 25 obese and overweight are included with age matched controls who came to chalmeda anadrao institute of medical sciences hospital. The Fasting blood glucose (FBS), lipid profile, SOD, MDA levels are measured. Results: The mean \pm SD values of FBS of samples with history of diabetes (146.3 \pm 11.68$)$ and without history of diabetes $(95 \pm 4.02)$ compared to controls are $(88.33 \pm 6.78)$ which is significant with $p<0.001$. The antioxidant enzyme levels in controls and samples are SOD mean \pm SD samples $(50 \pm 4.96)$ controls $(100 \pm$ 4.62), MDA samples are (619.12 \pm 0.91$)$ controls $(240.4 \pm 1.14)$. The comparison of lipid profile of samples with controls are also significant with p value $<0.001$. Discussion: In normal healthy condition there is always redox homeostasis occurring in cell, any imbalance to this redox homeostasis leads to oxidative stress (OS). OS leads to overproduction of ROS and impairs antioxidant defense mechanism. Increased metabolic and mechanical load on myocardium, large body mass, nutritious diet leads to formation of lipid peroxidation, freeradical and reactive oxygen species generation which inturn impairs insulin receptors functioning leads to insulin resistance, metabolic syndrome, type 2 diabetes. Conclusion: From this study we conclude that regular physical activity, diet restriction, and early assessment of SOD, MDA levels we can prolong the complications of type 2 diabetes.
\end{abstract}

Keywords: obesity, antioxidant enzymes, reactive oxygen species (ROS), oxidative stress, type 2 Diabetes

Cite This Article: Kandi Sabitha, B. Venugopal, Md Rafi, and K V Ramana, "Role of Antioxidant Enzymes in Glucose and Lipid Metabolism in Association with Obesityand Type 2 Diabetes." American Journal of Medical Sciences and Medicine, vol. 2, no. 1 (2014): 21-24. doi: 10.12691/ajmsm-2-1-5.

\section{Introduction}

Aerobic organisms possess antioxidant defense system that deals with reactive oxygen species (ROS). ROS is produced by partial reduction of oxygen which is highly reactive substance. They are normally produced in response to both internal and external stimuli $[1,2,3]$. High

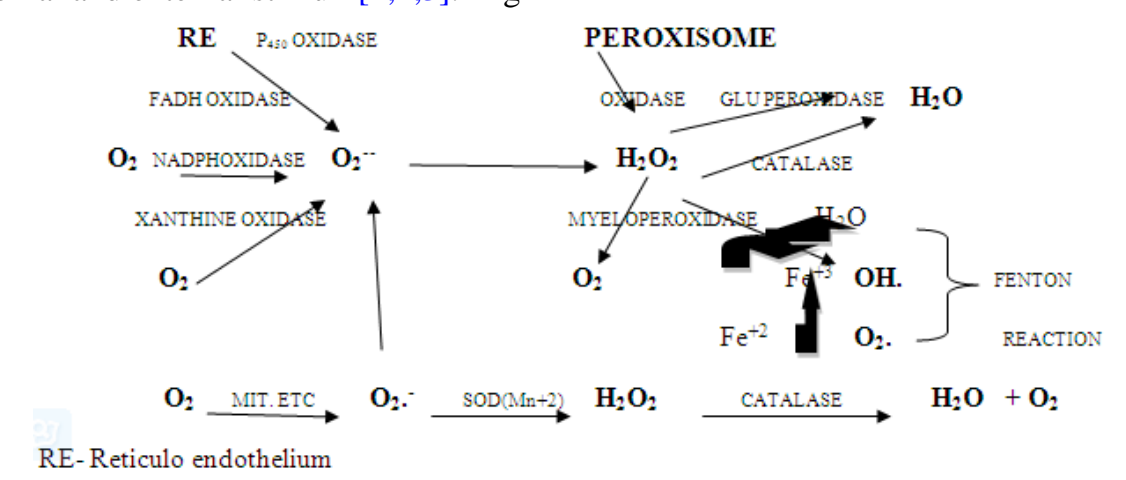

RE- Reticulo endothelium levels of ROS or inadequate removal of reactive substances results in oxidative stress, which causes severe malfunction and damage to biological macromolecules $[4,5]$. The mechanism of enzymatic and non-enzymatic functions of antioxidant enzymes which are essential for survival of organisms and their health is complex. [9] (Figure 1).

Figure 1. generation of ros \& defnse by antioxidant enzymes 
Obesity is a state of excess adipose tissue deposition. The most widely used method to measure obesity is by Body Mass Index (BMI). It is calculated as

$$
\mathrm{BMI}=\text { Weight in Kilogram } /(\text { Height in metre })^{2}
$$

Other methods like anthropometry (skin fold thickness), densitometry (underwater weighing), computer tomography (CT) \& magnetic resonance Imaging (MRI) are also used as an indices to measure obesity [10]. The classification of obesity and waist circumference are shown in (Table 1).

$$
\begin{aligned}
& \text { Normal range: } \\
& \text { Males \& Females }-19 \text { to } 26 \mathrm{Kg} / \mathrm{m}^{2} \\
& \text { Waist circumference : } \\
& \text { Men }<102 \mathrm{~cm} \& \text { Women }<88 \mathrm{~cm}
\end{aligned}
$$

Waist circumference is used as a surrogate marker for upper body obesity. Waist circumference $>102 \mathrm{~cm}$ in men and $>88 \mathrm{~cm}$ in women increases the risk for metabolic syndrome. Available literature reveals that the prevalence of diabetes is 2.9 times higher in overweight than in normal persons $[11,12]$.

Table 1. The classification of obesity and waist circumference

\begin{tabular}{|c|c|c|c|}
\hline classification & bmi & obesity class & waist circumference \\
\hline under weight & $\leq 19$ & - & - \\
\hline overweight & $25-30$ & - & i \\
\hline obese & $30-35$ & ii & increase slightly \\
\hline extremely obese & $35-40$ & iii & very high \\
\hline
\end{tabular}

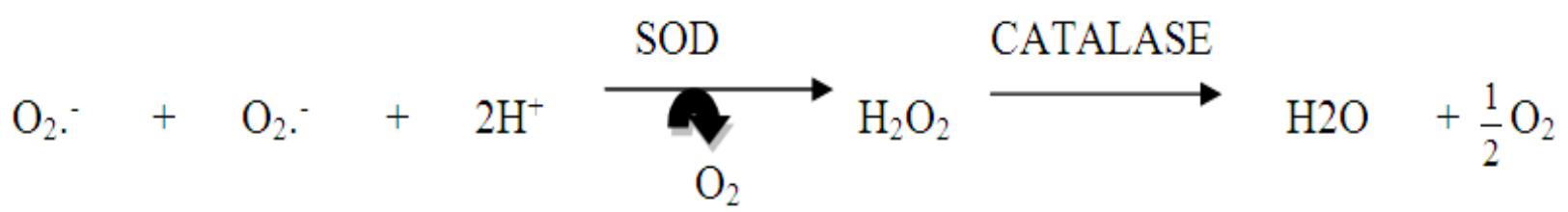

\subsection{Antioxidant Enzymes}

\subsubsection{Superoxide Dismutase (SOD)}

This enzyme catalyses dis-mutation of highly reactive superoxide anion to $\mathrm{O}_{2}$ and less reactive $\mathrm{H}_{2} \mathrm{O}_{2}$.

It requires metal co-factors like $\mathrm{Cu} / \mathrm{Zn} / \mathrm{Mn} / \mathrm{Fe}$. In humans $\mathrm{Cu} / \mathrm{Zn}$ SOD is present in cytosol, while Mn SOD is present in mitochondria. There also exists a third form of SOD in Extracellular fluid (ECF) that contains $\mathrm{Cu} \&$ $\mathrm{Zn}$ in its active site. The mitochondrial form of SOD is biologically important. SOD is measured by the Worthington method using inhibiting enzyme by oxygen dependent reaction [13].

\subsubsection{Malondialdehyde (MDA)}

It is generated from reactive oxygen species (ROS). MDA is reactive and potentially mutagenic, found in heated edible oils like sunflower and Palm oil [14]. MDA condenses with two molecules of thiobarbituric acid to give fluorescent red derivative that can be assayed spectrophotometrically [15].

The aim of the present study is to identify persons with obesity using BMI/Waist circumference and measure biochemical parameters like fasting blood glucose (FBS), lipid profile, SOD and MDA levels.

\section{Materials \& Methods}

A total of twenty-five subjects (16 males \& 9 females) aged $>35$ years were included in the study. All the study groups including the controls were attending Chalmeda Anand Rao Institute of Medical Sciences (CAIMS) Hospital, Karimnagar, Andhrapradesh, India.

\subsection{Inclusion Criteria}

$\mathrm{BMI}>26 \mathrm{Kg} / \mathrm{m}^{2}$.

Waist Circumference men $>102 \mathrm{~cm}$.

History of obesity in family, diabetes.

Hepatic diseases.

\subsection{Exclusion Criteria}

Hepatic diseases.

Renal disorders.

Cardiovascular problems.

Blood samples are collected $(5 \mathrm{ml})$ after 12 hours of fasting and were dispensed into a clean dry test tube (3ml), fluoride coated tube $(1 \mathrm{ml})$ and EDTA coated tube $(1 \mathrm{ml})$. The lipid profile and FBS were performed in fully automated analyzser (BS 300 MINDRAY); SOD and MDA were measured spectrophotometrically.

\section{Results}

The FBS values of the study subjects were divided into two groups; those having history of diabetes and those who were obese (BMI/Waist circumference) which included both males and females were compared. The mean \pm SD values of FBS of samples with history of diabetes $(146.3 \pm 11.68)$ and without history of diabetes $(95 \pm 4.02)$ compared to controls $(88.33 \pm 6.78)$ was statistically significant $(p<0.001)$. The antioxidant enzyme levels in study groups and controls were SOD (50 \pm 4.96) $(100 \pm 4.62)$; MDA (619.12 \pm 0.91$)(240.4 \pm 1.14)$. The comparison of lipid profile of study subjects with controls was also significant $(p<0.001)$. The detailed values of all the parameters are shown in (Table 2) \& (Table 3). 
Table 2 . The mean \pm SD values of all the parameters of the study subjects

\begin{tabular}{|c|c|c|c|c|c|c|c|c|c|}
\hline & $\begin{array}{c}\text { WC(waist } \\
\text { circumferenc } \\
\text { e) }\end{array}$ & $\begin{array}{c}\text { FBS(fasting } \\
\text { blood } \\
\text { glucose) }\end{array}$ & $\begin{array}{l}\mathrm{CHO} \text { (cholester } \\
\text { ol) }\end{array}$ & $\begin{array}{l}\text { TG(triglycerid } \\
\text { es) }\end{array}$ & $\begin{array}{c}\text { LDL(low } \\
\text { density } \\
\text { lipoprotein) }\end{array}$ & $\begin{array}{l}\text { VLDL(ve } \\
\text { ry low } \\
\text { density } \\
\text { lipoprotei } \\
\text { n) } \\
\end{array}$ & $\begin{array}{l}\text { HDL(hig } \\
\text { h density } \\
\text { lipoprotei } \\
\text { n) }\end{array}$ & $\begin{array}{l}\text { MDA(mal } \\
\text { on } \\
\text { dialdehyde } \\
\text { ) }\end{array}$ & $\begin{array}{l}\text { SOD(superoxi } \\
\text { de dismutase) }\end{array}$ \\
\hline $\begin{array}{l}\text { Mea } \\
n \\
\pm \mathrm{SD}\end{array}$ & $\begin{array}{c}104.11 \\
\pm 6.79\end{array}$ & $\begin{array}{c}146.3 \\
\pm 11.68 \text { (with } \\
\text { H/O DM) } \\
95 \pm 4.02 \text { (with } \\
\text { out H/O DM) }\end{array}$ & $212.6 \pm 10.7$ & $190.56 \pm 13.77$ & $\begin{array}{c}141.36 \pm 11 \\
32\end{array}$ & $\begin{array}{c}38.06 \pm 2.6 \\
9\end{array}$ & $\begin{array}{c}32.36 \pm 2.9 \\
1\end{array}$ & $\begin{array}{c}619.12 \pm 0 \\
91\end{array}$ & $50 \pm 4.92$ \\
\hline
\end{tabular}

Table 3. The mean \pm SD values of all parameters among control subjects

\begin{tabular}{|c|c|c|c|c|c|c|c|c|c|}
\hline & $\begin{array}{l}\text { WC(waist } \\
\text { circumferen } \\
\text { ce) }\end{array}$ & $\begin{array}{l}\text { FBS(fastin } \\
\text { g blood } \\
\text { glucose) }\end{array}$ & $\begin{array}{c}\mathrm{CHO} \text { (cholest } \\
\text { erol) }\end{array}$ & $\begin{array}{l}\text { TG(triglycerid } \\
\text { es) }\end{array}$ & $\begin{array}{l}\text { LDL(low } \\
\text { density } \\
\text { lipoprotei } \\
\text { n) }\end{array}$ & $\begin{array}{l}\text { VLDL(ve } \\
\text { ry low } \\
\text { density } \\
\text { lipoprotei } \\
\text { n) } \\
\end{array}$ & $\begin{array}{l}\text { HDL(hig } \\
\text { h density } \\
\text { lipoprotei } \\
\text { n) }\end{array}$ & $\begin{array}{l}\text { MDA(malon } \\
\text { dialdehyde) }\end{array}$ & $\begin{array}{l}\text { SOD(superox } \\
\text { ide } \\
\text { dismutase) }\end{array}$ \\
\hline $\begin{array}{c}\text { Mea } \\
\mathrm{n} \\
\pm \mathrm{SD} \\
\end{array}$ & $78.11 \pm 0.93$ & $\begin{array}{l}88.33 \\
\pm 6.78\end{array}$ & $163.28 \pm 5.98$ & $136.8 \pm 14.62$ & $90 \pm 6.1$ & $\begin{array}{c}26.68 \pm 2 . \\
32\end{array}$ & $\begin{array}{c}46.68 \pm 4 . \\
67\end{array}$ & $240.44 \pm 1.1$ & $100 \pm 4.67$ \\
\hline
\end{tabular}

\section{Discussion}

The tissues are protected from oxidative injury by expressing stress- response genes and genes coding for anti-oxidant enzymes and also by activating transcriptional regulatory proteins. The anti-oxidant defense system helps in maintaining normal cellular physiology, prevents diseased condition and also promotes immunity [16]. In normal healthy individuals there is always redox homeostasis occurring in cell, and any imbalance to this redox homeostasis leads to oxidative stress (OS). OS contributes to over production of ROS and impairs antioxidant defense mechanism [17].

Obesity increases the OS by the following mechanisms. (myocardium [18], cell injury [19], lipid per oxidation [20]).

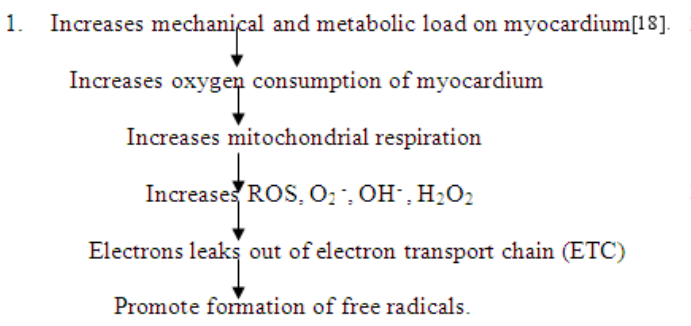

All these mechanisms lead to stimulation of antioxidant enzymes but over a period of time the stores of antioxidant enzymes are depleted and cannot cope with increasing OS [21]. In obesity there is excess adipose tissue which contains fatty acids as triglycerides. The enhanced sympathetic state of obesity in turn stimulates lipolysis, releasing excessive quantities of free fatty acids. This leads to lipo toxicity and OS in endoplasmic reticulum and mitochondria. These increased free fatty acids (FFA) inhibit lipogenesis; thus increases triglycerides in serum leading to hypertriglyceridemia [22,23,24,25].

\section{OBESITY}

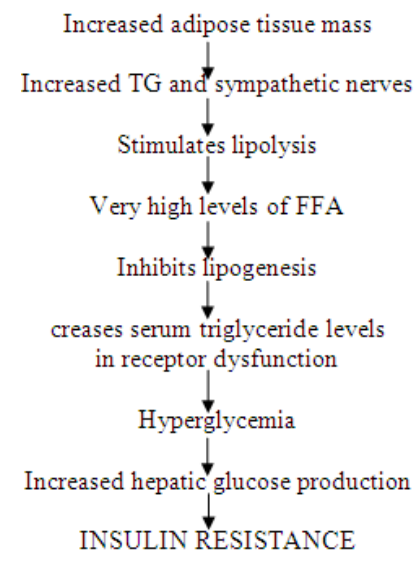

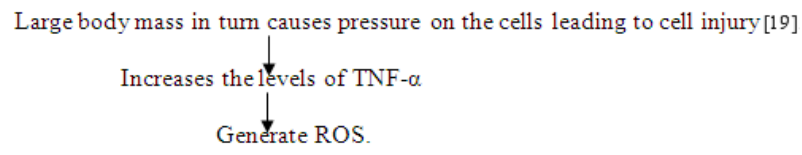

Large body mass in tum causes pressure on the cells leading to cell injury [19] Increases the levels of TNF- $\alpha$ Generate ROS.

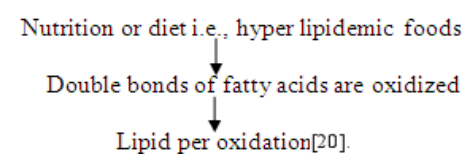

In the present study there is increased MDA levels ( $\mathrm{p}<$ 0.001) in obese individuals due to lipid per oxidation and SOD levels were decreased $(p<0.001)$ which indicates decline of antioxidant defense capacity among obese individuals. The study results also confirm the altered lipid metabolism in obese individuals.

\section{Conclusion}

From this study we conclude and re-emphasize the role of obesity in the development of oxidative stress and disturbed lipid metabolism. Therefore early detection of obesity i.e., by BMI / waist circumference or predisposing genetic factors and regular assessment of biochemical parameters including oxidative stress markers is required to minimize the complications arising from type 2 diabetes and obese individuals to increase the life expectancy.

\section{References}

[1] Hurst R, Bao Y, Jemth P, Mannervik B, Williamson G. Phosholipid hydroperoxide glutathione peroxidase activity of rat class theta glutathione transferase T2-2. Biochem Soc Trans 1997; 25: S559.

[2] Jornot L, Petersen H, Junod AF. Hydrogen peroxide - induced DNA damage is independent of nuclear calcium but dependent on redox-active ions. Biochem J 1998; 335: 85-94. 
[3] Mills EM, Takeda K, Yu Zx, et al, Nerve growth factor treatment prevents the increase in superoxide produced by epidermal growth factor in PC 12 cells. J Biol Chem 1998; 273: 22165-8.

[4] Chopra S, Wallace HM. Induction of spermidine / spermine N1acetyl transferase in human cancer clls in response to increased production of reactive oxygen species. Biochem Pharmacol 1998; 55: 1119-23.

[5] Czen S, Tiback M, Harms - Ringdahl M. pH dependent DNA cleavage in permeabilized human fibroblasts. Biochem J 1997; 323: 337-41.

[6] Scott MD, Eaton JW, Kuypers FA, Chiu DT, Lubin BH. Enhancement of erythrocyte superoxide dismutase activity: effects on cellular oxidant defense. Blood 1989; 74: 2542-9.

[7] Stahl W, Junghans A, de Boer B, Driomina ES et al. Carotenoid mixtures protect multilamellar liposomes against oxidative damage: Synergistic effects of lycopene and lutein. FEBS Lett 1998; 427: 305-8.

[8] Hall L, Williams K, Perry ACF, Frayne J, Jury JA. The majority of human glutathione peroxide type 5 (GPX 5) transcripts are incorrectly spliced: implications for the role of GPX5 in the male reproductive tract. Biochem J 1998: 333: 5-9.

[9] Grazoli V, Schiavo R, Casari E, et al. Antioxidant enzymatic activities and lipid peroxidation in cultured human chondrocytes from vertebral plate cartilage. FEBS Lett 1998; 431: 149-53.

[10] Jeffrey S. Flier, Eleftheria Maratos Flier. Harrisons Principles of Internal Medicine: chapter 64: Obesity; 16th edition; McGraw Hill Medical Publishing division: 2005; vol I: 422.

[11] National Institutes of Health Consensus Development Panel on the Health Implications of Obesity. 1985. Health implications of Obesity: National Institutes of Health Consensus Development Conference statement. Ann Intern Med; 103: 1073-77.

[12] Ramachandran A. 2005. Epidemiology of diabetes in India - 3 decades of research. JAPI; 53: 34-38.

[13] Bannister J, Bannister W, Rotilio G. 1987. "Aspects of the structure,function and applications of SOD. Critical Rev Biochem 22: $111-180$.
[14] Dourerdjou P, Koner B.C (2008), Effects of different cooking vessels on heat induced lipid peroxidation of different edible oils. Journal of Food Biochemistry, 32: 740-751.

[15] V. Nair, C.L.O Neil, P.G.Wang. 'Malondialdehyde, Encyclopedia of reagents for organic synthesis, 2008. Johnweily \& Sons. Newyork.

[16] Jose M Mates, Cristins perez-Gomez, Ignacio nunez de castro. 'Antioxidant enzymes and human diseases'. Clinical Biochemistry, 32: 8: 5 95-603, 1999.

[17] Furukawa S, Fujiti T, Shimabukuro M, Iwaki M, Yamada Y et al. Increased oxidative stress in obesity and its impact on metabolic syndrome. The Journal of clinical Investigation 114 (12): 17521761, 2004.

[18] Turrens JF: Superoxide production by the mitochondrial respiratory chain. Bio Sci Rep 17: 3-8, 1997.

[19] Lechieitner M, KochT, Harold M, Dzien A, Hoppiahler F; TNF- $\alpha$ plasma levele in patients with type 1 Diabete mellitus and its association with glycemic control \& cardiovascular risk factors. J Intern Med; 248: 67- 76, 2000.

[20] Moor de Burgos A, Wartonowics M, Ziemlanski S : Blood vitamin \& lipid levels in overweight \& obese women. Eur J Clin Nutr 46: 803-808, 1992.

[21] Alexander CM, Landsman PB, Teutsch SM: Diabetes melliteus impairing fasting glucose, atherosclerotic risk factors \& prevelance of coronary heart disease. Am J Cardiol 86; 897-902, 2000.

[22] Redinger RN.2007, Pathophysiology of obesity and its clinical manifestations. Gastroenterology \& Hepatology, 3: 856-863.

[23] Evans RM, Barish GD, Wang YX.2004.PPARS and the complex journey to obesity. Nat Med 10: 355-361.

[24] Hutley L, Prins JB.2005. fat as an endocrine organ: relationship to the metabolic syndrome. Am J Med Sci 330; 280-289.

[25] Boden G, ChenX, Riuz J, White JV, Rosseti L.1994. Mechanism of fattyacid induced inhibition of glucose uptake. J Clin Invest, 93: 2438-2446. 